\title{
Anti-CCP antibodies and rheumatoid factor in systemic sclerosis: Prevalence and relationships with joint manifestations
}

\author{
Ewa Wielosz ${ }^{A-F}$, Maria Majdan ${ }^{A, C, E, F}$, Magdalena Dryglewska ${ }^{B, C}$, Robert Zwolak ${ }^{B, C, E}$ \\ Department of Rheumatology and Connective Tissue Diseases, Medical University of Lublin, Poland \\ A - research concept and design; $B$ - collection and/or assembly of data; $C$ - data analysis and interpretation; \\ $D$ - writing the article; $E$ - critical revision of the article; $F$ - final approval of the article
}

Address for correspondence

Ewa Wielosz

E-mail: ewa.wielosz@wp.pl

Funding sources

None declared

Conflict of interest

None declared

Received on 0ctober 30, 2016

Reviewed on December 14, 2016

Accepted on March 28, 2017

\begin{abstract}
Background. It is known that anti-citrullinated protein (a-CP) antibodies and rheumatoid factor (RF) can be present in systemic sclerosis (SSc) patients, particularly with joint involvement.

Objectives. The aim of the study was to assess the prevalence of a-CCP antibodies and immunoglobulin M class (IgM) RF, and the relationships between their presence and joint manifestations in patients with SSC.

Material and methods. The study included 100 European Caucasian SSc patients hospitalized consecutively in the Department of Rheumatology and Connective Tissue Diseases (Lublin, Poland). Anti-citrullinated protein antibodies and lgM RF were determined using a commercial enzyme-linked immunosorbent assay (ELISA) test.
\end{abstract}

Results. Anti-citrullinated protein antibodies were found in 10 out of 100 (10\%) SSc patients and IgM RF in 71 out of 100 (71\%) SSc patients. In the study, 90/100 (90\%) SSc patients had joint manifestations (arthralgia or arthritis), 34/100 (34\%) had arthritis and 6/100 (6\%) had a systemic sclerosis-rheumatoid arthritis (SSC-RA) overlap syndrome. Significantly higher a-CCP antibody levels ( $p=0.012$ ), erythrocyte sedimentation rate (ESR) $(p=0.029)$ and $(-$ reactive protein (CRP) levels $(p=0.020)$ were observed in the SSc group with arthritis. A significant correlation was found between the group with arthritis and the presence of a-CCP antibodies, and between the arthralgia group and the presence of IgM RF.

Conclusions. The prevalence of RF and a-CCP antibodies is relatively high in SSC, and joint involvement occurs frequently. There was a significantly higher prevalence of $\operatorname{lgM} R \mathrm{RF}$ in the group with joint manifestations. About $1 / 3$ of SSc patients had symptoms of arthritis. Arthritis is connected with the presence of a-CCP antibodies, while arthralgia is connected with the presence of IgM RF.

Key words: systemic sclerosis, arthritis, rheumatoid factor, anti-citrullinated protein antibodies, arthralgia

DOI

$10.17219 /$ acem/69921

Copyright

Copyright by Author(s)

This is an article distributed under the terms of the

Creative Commons Attribution Non-Commercial License

(http://creativecommons.org/licenses/by-nc-nd/4.0/) 


\section{Introduction}

Systemic sclerosis (SSc) is a multisystem disorder characterized by vascular damage, immune activation and fibroblast activation, changes which lead to a progressive thickening of the skin with structural and functional abnormalities of different organs. Musculoskeletal involvement is present in $24-97 \%$ of SSc patients. ${ }^{1-3}$ A more common manifestation is arthralgia, whereas arthritis is rare. ${ }^{4,5}$ Hand involvement is often the first clinical manifestation of SSc. ${ }^{6,7}$ Symmetrical polyarthritis similar to rheumatoid arthritis (RA) can also be found in SSc, but it particularly characterizes a systemic sclerosis-rheumatoid arthritis (SSc-RA) overlap syndrome. ${ }^{2,8-10}$ In some cases, arthritis in the course of SSc and SSc-RA overlap syndrome can be very difficult to distinguish. It is known that the main serological markers for diagnosing RA are anti-citrullinated protein (a-CCP) antibodies and rheumatoid factor (RF). These parameters can be present in SSc patients, particularly with joint involvement. ${ }^{1,2,8}$ The aim of the study was to assess the prevalence of a-CCP antibodies and immunoglobulin M class (IgM) RF, and the relationships between their presence and joint manifestations in patients with SSc.

\section{Material and methods}

The study included 100 European Caucasian SSc patients (82 female and 18 male) hospitalized consecutively in the Department of Rheumatology and Connective Tissue Diseases (Lublin, Poland). The patients fulfilled the American College of Rheumatology (ACR) classification criteria of SSc (Table 1). ${ }^{11}$ Serum samples were obtained from 100 patients and a joint examination was performed at the same time. Anti-citrullinated protein antibodies and

Table 1. Characteristics of the SSc study group

\begin{tabular}{|l|c|}
\multicolumn{1}{|c|}{ Characteristics } & Patients' data \\
\hline Number of patients & 100 \\
\hline SSc subtype & dcSSC -50 \\
\hline Age [years] & IcSSC -50 \\
\hline Duration of disease [years] & $52.68 \pm 13.85$ (range 18-81) \\
\hline ACA & $6.46 \pm 6.05$ (range 0.1-23) \\
\hline Anti-Scl-70 & $19 / 100(19 \%)$ \\
\hline Overlap syndrome & $46 / 100(46 \%)$ \\
\hline SSc/RA & $21 / 100(21 \%)$ \\
\hline SSc/SS & $6 / 100(6 \%)$ \\
SSc/DM/PM & $8 / 100(8 \%)$ \\
\hline
\end{tabular}

SSc - systemic sclerosis; dcSSC - diffuse cutaneous SSc; IcSSC - limited cutaneous SSC; ACA - anti-centromere antibodies; anti-SCI-70 - antitopoisomerase I antibodies; RA - rheumatoid arthritis; SS - Sjögren's syndrome; DM/PM - dermatomyositis/polymyositis.

Data is presented as mean \pm standard deviation (SD), number and percentage.
IgM RF were determined using the enzyme-linked immunosorbent assay (ELISA) commercial test : EUROIMMUN for IgM RF (EUROIMMUN AG, Lübeck, Germany) and INOVA for a-CCP antibodies (INOVA Diagnostics, San Diego, USA). The test kit was used according to the manufacturer's suggested procedures. The samples were classified as negative for a-CCP antibodies at $<20$ units and negative for IgM RF at $<30 \mathrm{RU} / \mathrm{mL}$. Two markers of inflammation, erythrocyte sedimentation rate (ESR) and $\mathrm{C}$-reactive protein (CRP), were also determined. The samples were classified as negative for ESR at $<16 \mathrm{~mm} / \mathrm{h}$ for women and at $<11 \mathrm{~mm} / \mathrm{h}$ for men, and at $<10 \mathrm{mg} / \mathrm{L}$ for CRP. Joint involvement was assessed according to clinical manifestations, such as arthralgia or arthritis. Arthralgia was assessed by involving 2 or more peripheral joints characterized by tenderness. Non-erosive arthritis was determined by involving 2 or more peripheral joints characterized by tenderness and swelling or confirmed by ultrasonography (USG). Moreover, flexion contractures, tendon friction rubs (TFRs) and finger-to-palm distance in flexion (FTP) were assessed. Finger-to-palm distance in flexion was determined by measuring the minimal distance $(\mathrm{mm})$ between the nail tip of the middle finger and the transverse palmar creases in both hands (normally no distance can be measured). ${ }^{12}$ Rheumatoid arthritis was diagnosed according to the ACR criteria. ${ }^{13}$ Anti-topoisomerase I (a-Scl-70) and anti-centromere antibodies (ACA) were determined using a commercial test, the EUROLINE Systemic Sclerosis Profile (EUROIMMUN AG, Lübeck, Germany).

All calculations were performed with STATISTICA v.10.0 software (StatSoft, Kraków, Poland). Data was analyzed using the non-parametric $X^{2}$ test for comparisons between the groups. Quantitative data was assessed using the Mann-Whitney U test, whereas qualitative data was determined by the Yule correlation. Probability value $\mathrm{p}<0.05$ was considered statistically significant.

\section{Results}

According to our observations, 90 out of the 100 (90\%) SSc patients had arthralgia, 34 (34\%) SSc patients had arthritis and 24 (24\%) SSc patients developed flexion contractures. Finger-to-palm distance in flexion was decreased in 26 out of 100 (26\%) SSc patients, while 5 (5\%) SSc patients had TFRs. An SSc-RA overlap syndrome was found in 6 (6\%) SSc patients. The mean disease activity score 28 (DAS 28) in the group with an SSc-RA overlap syndrome was $4.46 \pm 1.29$. The prevalence of IgM RF and a-CCP antibodies in SSc patients with and without joint manifestations is presented in Table 2 .

In the SSc study group without overlapped RA, 28 patients had arthritis, 65 patients were positive for IgM RF and 7 patients were positive for a-CCP antibodies. In the group of 28 SSc patients with arthritis, IgM RF was present in 19 patients (68\%), at a high value in $15(54 \%)$ patients and 
Table 2. The prevalence of IgM RF and a-CCP antibodies in SSc patients with and without joint manifestations

\begin{tabular}{|c|c|c|c|c|c|}
\hline \multirow{2}{*}{$\begin{array}{l}\text { Prevalence of IgM RF } \\
\text { and a-CCP antibodies }\end{array}$} & \multirow{2}{*}{ Total } & \multicolumn{2}{|c|}{ Group with joint manifestations } & \multirow{2}{*}{$\begin{array}{l}\text { Group without joint } \\
\text { manifestations }\end{array}$} & \multirow{2}{*}{$\mathrm{p}$-value } \\
\hline & & arthralgia & arthritis & & \\
\hline Number of patients & 100 & $\begin{array}{c}90 / 100 \\
(90 \%)\end{array}$ & $\begin{array}{c}34 / 100 \\
(34 \%)\end{array}$ & $\begin{array}{c}10 / 100 \\
(10 \%)\end{array}$ & - \\
\hline \multirow[t]{2}{*}{$\operatorname{lgM} R F$} & \multirow{2}{*}{$\begin{array}{c}71 / 100 \\
(71 \%)\end{array}$} & \multirow{2}{*}{$\begin{array}{l}67 / 90 \\
(74.4 \%)\end{array}$} & $\begin{array}{l}25 / 34 \\
(73.5 \%)\end{array}$ & $\begin{array}{l}4 / 10 \\
(40 \%)\end{array}$ & \multirow[t]{2}{*}{0.023} \\
\hline & & & \multicolumn{2}{|c|}{$p=0.049$} & \\
\hline \multirow[t]{2}{*}{ a-CCP antibodies } & \multirow[t]{2}{*}{$\begin{array}{c}10 / 100 \\
(10 \%)\end{array}$} & \multirow{2}{*}{$\begin{array}{l}9 / 90 \\
(10 \%)\end{array}$} & $\begin{array}{c}7 / 34 \\
(20.6 \%)\end{array}$ & $\begin{array}{l}1 / 10 \\
(10 \%)\end{array}$ & \multirow[t]{2}{*}{ NS } \\
\hline & & & \multicolumn{2}{|c|}{ NS } & \\
\hline
\end{tabular}

IgM RF - immunoglobulin M class rheumatoid factor; a-CCP - anti-citrullinated protein; SSC - systemic sclerosis; NS - nonsignificant. Data is presented as number and percentage; $p$-value of $<0.05$ was considered statistically significant.

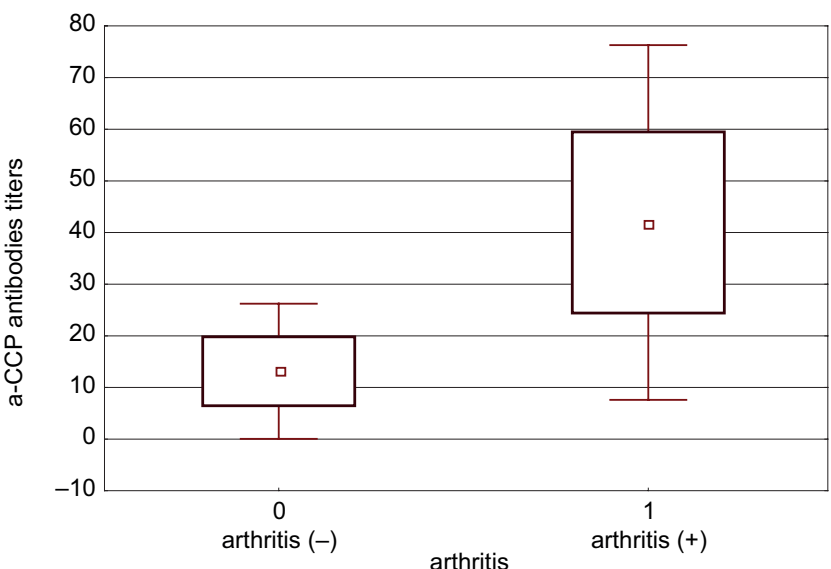

Fig. 1. Statistically significant differences in the titers of a-CCP antibodies in groups with and without arthritis

a-CCP - anti-citrullinated protein; probability value: $p=0.0119$.

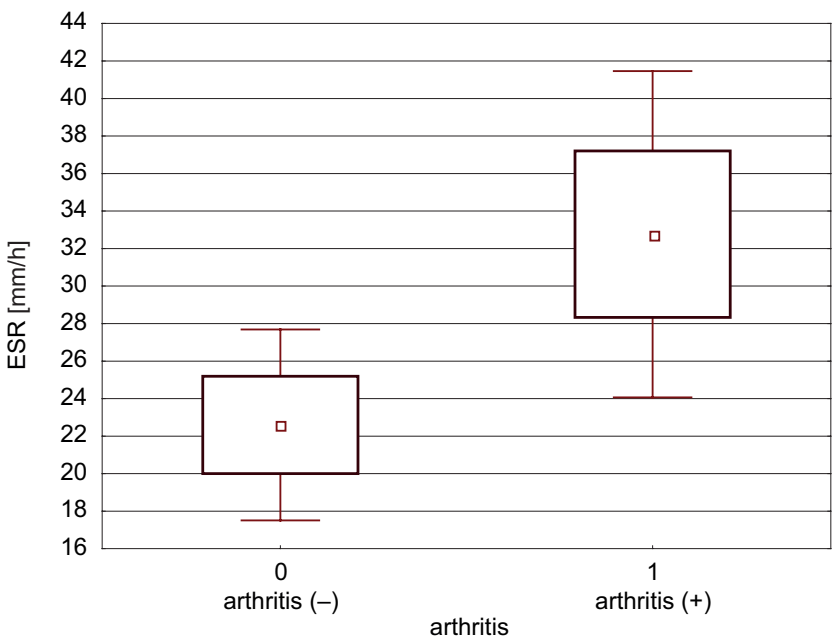

Fig. 2. Statistically significant differences in ESR in groups with and without arthritis

ESR - erythrocyte sedimentation rate; probability value: $p=0.0294$.

at a low value in $4(14 \%)$ patients. Moreover, a-CCP antibodies were present in 4 out of 28 patients (14\%) with arthritis, $3(11 \%)$ with a high value and 1 (3\%) with low. In the group of 66 SSc patients without arthritis, 46 patients (70\%) were positive for IgM RF, 32 (49\%) at a high value, 8 (12\%)

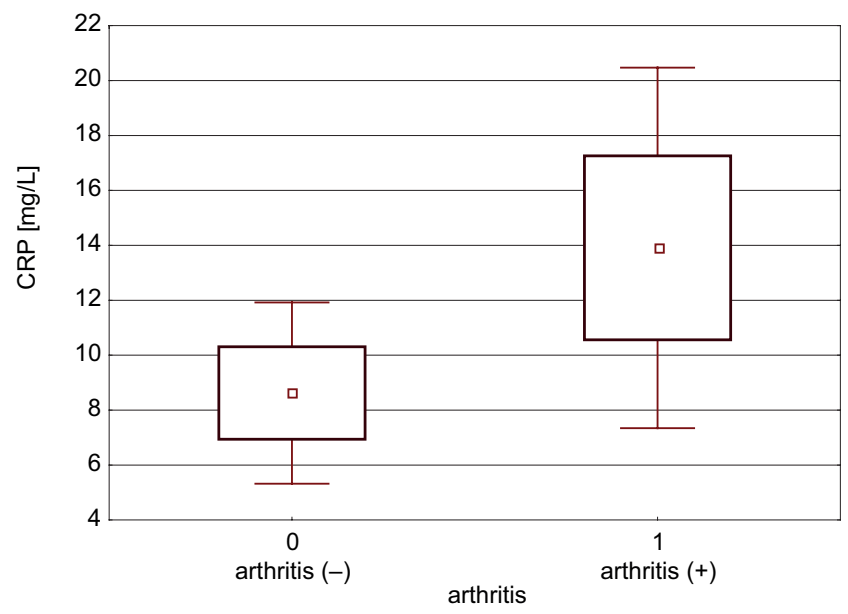

Fig. 3. Statistically significant differences in the titers of CRP in groups with and without arthritis

CRP - C-reactive protein; probability value: $p=0.0201$.

at a medium value and $6(9 \%)$ at a low value. Anti-citrullinated protein antibodies were found in $3(5 \%)$ SSc patients without arthritis, 1 (2\%) with a high value and $2(3 \%)$ with low. However, in the group of 46 patients with positive IgM RF without overlapped RA and without arthritis, 42 (91\%) patients had arthralgia. Our findings indicated that the prevalence of IgM RF was significantly higher in the group with joint manifestations compared to the group without it ( $\mathrm{p}=0.0230)$. However, no significant intergroup differences in the presence of a-CCP antibodies were determined (Table 2). Significantly higher concentrations of a-CCP antibodies $(\mathrm{p}=0.0119)$ and CRP $(\mathrm{p}=0.0201)$, as well as ESR ( $p=0.0294$ ) were observed in the SSc group with arthritis compared to the group without arthritis (Fig. 1-3). The titer of IgM RF was not significantly higher in the SSc group with arthritis $(\mathrm{p}=0.0713)$ than in the group without arthritis. Interestingly, a significant correlation was determined between the SSc group with arthritis and the presence of a-CCP antibodies ( $\mathrm{p}=0.013 ; \Phi=0.263)$ and between the SSc group with arthralgia and the presence of IgM RF ( $p=0.025 ; \Phi=0.238$ ). Moreover, a significant correlation was noted between the SSc group with arthritis and the concentrations of inflammatory parameters (ESR and CRP) (Table 3). 
Table 3. Correlations between IgM RF, a-CCP antibodies, inflammation parameters and joint involvement

\begin{tabular}{|l|c|c|c|}
\multicolumn{1}{c|}{ Joint manifestations } & ESR & CRP & IgM RF \\
\hline Arthritis & $P=0.0158$ & $p=0.050$ & $p=0.481$ \\
& $\Phi=0.234$ & $\Phi=0.192$ & $\Phi=0.073$ \\
Arthralgia & $p=0.467$ & $p=0.844$ & $p=0.025$ \\
& $\Phi=0.070$ & $\Phi=0.025$ & $\Phi=0.238$ \\
\hline
\end{tabular}

ESR - erythrocyte sedimentation rate; CRP - C-reactive protein; IgM RF - immunoglobulin M class rheumatoid factor; a-CCP - anti-citrullinated protein; p-value of $<0.05$ was considered statistically significant.

\section{Discussion}

In the present study, we investigated the presence of serological parameters of joint involvement: a-CCP antibodies and IgM RF in SSc. According to our observations, a-CCP antibodies were found in 10\% of SSc patients. Our findings are similar to those reported in the literature. Polimeni et al. demonstrated that in a SSc group, 7 of 78 (9\%) patients were a-CCP positive. ${ }^{2}$ According to Ingegnoli et al., the presence of a-CCP antibodies was detected in 8 of 75 (10.7\%) patients with SSc. ${ }^{1}$ Other studies showed that a-CCP antibodies were revealed in 18 out of $146(12.3 \%), 3$ out of 28 (10.7\%), 11 out of $82(13.4 \%)$, and 3 out of 114 (2.6\%) SSc patients. ${ }^{6,14-17}$ Moreover, Horimoto and Costa found a-CCP antibodies in 4 out of 24 patients (16.7\%), but all patients had an SSc-RA overlap syndrome. ${ }^{9}$ Based on literature data, we can suppose that a-CCP antibodies are a useful marker in identifying patients diagnosed with an SSc-RA overlap syndrome; however, these antibodies may also be positive in 7\% of SSc patients without arthritis. ${ }^{15}$ In our study, we also detected a-CCP antibodies in 10\% of SSc patients without joint involvement. There are many data indicating a significant association between positive a-CCP antibodies and arthritis and bone erosions in SSc. ${ }^{1,6,16,17}$ According to our findings, there was a significant correlation between the group of SSc patients with arthritis and the presence of a-CCP antibodies; higher titers of a-CCP antibodies were observed in the SSc group with arthritis compared to the group without arthritis. Additionally, the prevalence of IgM RF in SSc was evaluated; IgM RF was detected in $71 \%$ of patients, which seems to be higher than in other studies. According to our research, the prevalence of RF in SSc ranged from $12 \%$ to $35 \%$ and may be positive in SSc patients without joint manifestations. ${ }^{1,6,9,15,18,19}$ Avouac et al. suggested that the RF test seems non-specific and does not distinguish SSc patients with musculoskeletal manifestations from those unaffected by them. ${ }^{19}$ Rheumatoid factor may also be seen in patients with SSc associated with secondary Sjögren's syndrome, which is not uncommon in SSc patients. ${ }^{19}$ However, our results revealed that the prevalence of IgM RF was significantly higher in the group with joint manifestations as compared to the group without joint manifestations. This observation seemed to be associated with the presence of a large number of SSc patients with joint manifestations in our study group. According to our study, $90 \%$ of SSc patients had joint manifestations and $71 \%$ were positive for IgM RF, but only $6 \%$ developed an SSc-RA overlap syndrome. The above results suggest that the presence of RF or a-CCP antibodies in SSc patients does not lead to a diagnosis of an SSc-RA overlap syndrome. According to literature data, the search for anti-CCP antibodies might be of great help in some infrequent cases of an SSc-RA overlap syndrome, but not in all situations. ${ }^{19}$ Destructive joint disease in patients with SSc may suggest an overlap syndrome with RA. ${ }^{6,10}$ Numerous studies have reported such results. According to Arslan Tas et al., such radiographic findings as erosions, joint space narrowing and arthritis were less frequent in the SSc group, but acro-osteolysis, flexion contracture and calcinosis were more frequent than in the RA group. ${ }^{6}$ The abovementioned radiological findings can worsen the prognosis. Apart from hand radiography, the potential of USG in the assessment of joint and tendon involvement in the course of SSc was evaluated. Some studies revealed that SSc patients with a history of arthralgia without arthritis developed synovial inflammation, which could be observed during an USG examination, particularly in the wrist and small hand joints. ${ }^{20,21}$ Another important finding was that TFRs were part of functional impairment in SSc. ${ }^{22}$ Moreover, according to the largest worldwide database, joint and tendon involvement predict disease progression in SSc. ${ }^{23}$ Using the latest data from the European League Against Rheumatism (EULAR) Scleroderma Trials and Research (EUSTAR) cohort, this prospective study investigating 1,301 patients with SSc demonstrated that joint synovitis and TFRs were strong independent predictors of skin progression and that positivity for a-Scl-70 antibodies and a history of digital ulcers were also predictive markers. Furthermore, joint synovitis was predictive of the occurrence of decreased left ventricular ejection fraction and the occurrence of new digital ulcers. ${ }^{23}$ To sum up, according to literature data, hand arthropathy in SSc should alert one to functional damage, severe skin progression and serious internal organ involvement, particularly cardiopulmonary complications, which was the main cause of death in SSc. ${ }^{24-27}$ In conclusion, serological parameters which could predict severe articular involvement are needed. According to Generini et al., antibodies such as heterogeneous nuclear ribonucleoprotein isoform A1 
and A2 antibodies (anti-hnRNP-A1 and anti-hnRNP-A2) may have some diagnostic value for joint involvement and the risk of developing erosive arthritis in SSc. ${ }^{28}$

\section{Conclusions}

Immunoglobulin $\mathrm{M}$ class rheumatoid factor and a-CCP antibodies seem to be a helpful tool to differentiate cases with joint manifestations, although not in all patients. In our study, arthralgia was a common manifestation in SSc patients and the prevalence of RF was high in this group. Furthermore, RF correlated with arthralgia and a-CCP antibodies correlated with arthritis in SSc patients. Our study requires further analysis with the results based on clinical picture, USG and radiological joint examinations.

\section{References}

1. Ingegnoli F, Galbiati V, Zeni S, et al. Use of antibodies recognizing cyclic citrullinated peptide in the differential diagnosis of joint involvement in systemic sclerosis. Clin Rheumatol. 2007;26:510-514.

2. Polimeni M, Feniman D, Skare TS, Nisihara RM. Anti-cyclic citrullinated peptide antibodies in scleroderma patients. Clin Rheumatol. 2012;31:877-880.

3. Schmeiser T, Pons-Kühnemann J, Özden F, Müller-Ladner U, Dinser R Arthritis in patients with systemic sclerosis. Eur J Intern Med. 2012; 23:25-29.

4. Lima TR, Guimarães FS, Silva LA, Silva DP, Menezes SL, Lopes AJ. Relationship between functional capacity, joint mobility and pulmonary function in patients with systemic sclerosis. J Bodyw Mov Ther. 2015;19:17-24.

5. Chevreul K, Brigham KB, Gandré C, Mouthon L; BURQOL-RD Research Network. The economic burden and health-related quality of life associated with systemic sclerosis in France. Scand J Rheumatol. 2014, 18:1-9.

6. Arslan Tas D, Erken E, Sakalli H, Yucel AE. Evaluating hand in systemic sclerosis. Rheumatol Int. 2012;32:3581-3586.

7. Mouthon L. Hand involvement in systemic sclerosis. Presse Med. 2013 42:1616-1626.

8. Marrone M, Chialà A, Tampoia M, et al. Prevalence of anti-CCP antibodies in systemic sclerosis. Reumatismo. 2007;59:20-24.

9. Horimoto AM, Costa IP. Overlap between systemic sclerosis and rheumatoid arthritis: A distinct clinical entity? Rev Bras Reumatol. 2015;4: 482-504.

10. Chung L, Lin J, Furst DE, Fiorentino D. Systemic and localized scleroderma. Clin Dermatol. 2006;24:374-392.
11. Arslan Tas D; Subcommittee for scleroderma criteria of the American Rheumatism Association Diagnostic and Therapeutic Criteria Committee. Preliminary criteria for the classification of systemic sclerosis (scleroderma). Arthritis Rheum. 1980;23:581-590.

12. McHugh NJ, Distler O, Giacomelli R, Riemekasten G. Non organ based laboratory markers in systemic sclerosis. Clin Exp Rheumatol. 2003;21: 32-38.

13. Arnett FC, Edworthy SM, Bloch DA, et al. The American Rheumatism Association 1987 revised criteria for the classification of rheumatoid arthritis. Arthritis Rheum. 1988;31:315-324.

14. Payet J, Goulvestre C, Bialé L, et al. Anticyclic citrullinated peptide antibodies in rheumatoid and nonrheumatoid rheumatic disorders: Experience with 1162 patients. J Rheumatol. 2014;41:2395-2402.

15. Ueda-Hayakawa I, Hasegawa M, Kumada S, et al. Usefulness of anticyclic citrullinated peptide antibody and rheumatoid factor to detect rheumatoid arthritis in patients with systemic sclerosis. Rheumatology (Oxford). 2010;49:2135-2139.

16. Stamenković $B$, Stanković $A$, Dimić $A$, et al. The clinical significance of antibody determination to cyclic citrullinated peptides in systemic sclerosis. Srp Arh Celok Lek. 2012;140:350-354.

17. Morita Y, Muro Y, Sugiura K, Tomita Y. Anti-cyclic citrullinated peptide antibody in systemic sclerosis. Clin Exp Rheumatol. 2008;26:542-547.

18. Allali F, Tahiri L, Senjari A, Abouqal R, Hajjaj-Hassouni N. Erosive arthropathy in systemic sclerosis. BMC Public Health. 2007;7:260-266.

19. Avouac J, Clements PJ, Khanna D, Furst DE, Allanore Y. Articular involvement in systemic sclerosis. Rheumatology (Oxford). 2012;51: 1347-1356.

20. Iagnocco A, Vavala C, Vasile M, Stefanantoni K, Valesini G, Riccieri V. Power Doppler ultrasound of the hand and wrist joints in systemic sclerosis. Clin Exp Rheumatol. 2013;31:89-95.

21. Gutierrez M, Pineda C, Cazenave T, et al. Ultrasound in systemic sclerosis. A multi-target approach from joint to lung. Clin Rheumatol. 2014;33:1039-1047.

22. Stoenoiu MS, Houssiau FA, Lecouvet FE. Tendon friction rubs in systemic sclerosis: A possible explanation - an ultrasound and magnetic resonance imaging study. Rheumatology (Oxford). 2013;52:529-533.

23. Avouac J, Walker UA, Hachulla E, et al; EUSTAR collaborators. Joint and tendon involvement predict disease progression in systemic sclerosis: A EUSTAR prospective study. Ann Rheum Dis. 2016;75: 103-109.

24. Bálint Z, Farkas H, Farkas N, et al. A three-year follow-up study of the development of joint contractures in 131 patients with systemic sclerosis. Clin Exp Rheumatol. 2014;32:68-74.

25. Ingegnoli F, Boracchi P, Ambrogi F, Gualtierotti R, Galbiati V, Meroni PL. Hand impairment in systemic sclerosis: Association of different hand indices with organ involvement. Scand J Rheumatol. 2010;39: 393-397.

26. Fett N. Scleroderma: Nomenclature, etiology, pathogenesis, prognosis, and treatments: Facts and controversies. Clin Dermatol. 2013;31: 432-437.

27. Grant-Kels JM, Rothe MJ, Mease P. Rheumatology and dermatology: Part 1. Clin Dermatol. 2006;24:347.

28. Generini S, Steiner G, Miniati I, et al. Anti-hnRNP and other autoantibodies in systemic sclerosis with joint involvement. Rheumatology (Oxford). 2009;48:920-925. 